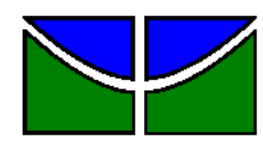

Universidade de Brasília

Faculdade de Economia, Administração e Contabilidade

Departamento de Administração

Curso de Graduação em Administração à distância

Henrique Fontenele Klein

Monumentos à memória dos que morreram: as necrópoles

e seu impacto ambiental

Brasília - DF

2010 
Henrique Fontenele Klein

\section{Monumentos à memória dos que morreram: as necrópoles e seu impacto ambiental}

Monografia apresentada a Universidade de Brasília (UNB) como requisito parcial para obtenção do grau de Bacharel em Administração.

Professor Orientador: Professora Mariana Marlière Létti - Mestre

Brasília - DF

2010 
Klein, Henrique Fontenele.

Monumentos à memória dos que morreram: as necrópolis e seu impacto ambiental / Henrique Fontenele Klein - Brasília, 2010. 45 f.: il.

Monografia (bacharelado) - Universidade de Brasília, Departamento de Administração - EaD, 2010.

Orientadora: Professora Mariana Marlière Létti, Departamento de Administração.

1. Necrochorume. 2. Cemitério. 3. Impacto Ambiental. I.Título. 


\section{Henrique Fontenele Klein}

\section{Monumentos à memória dos que morreram: as necrópoles e seu impacto ambiental}

A Comissão Examinadora, abaixo identificada, aprova o Trabalho de Conclusão do Curso de Administração da Universidade de Brasília do aluno

Henrique Fontenele Klein

Professora, Mariana Marlière Létti - Mestre

Professora-Orientadora

Professora, Maria Neuza da Silva Oliveira - Mestre

Professora-Examinadora 
Dedico este trabalho a toda a minha família, em especial a minha esposa Lucia, a minha filha Jéssica, meu pai Roberto e minha mãe Maria Tereza, pelo incentivo e paciência que demonstraram para mim, e que me possibilitou atingir este objetivo. 


\section{AGRADECIMENTOS}

Agradeço a Universidade de Brasília - UNB, pela oferta desta modalidade de curso, a todos os professores que me acompanharam durante esta jornada, a todos os colegas e um especial agradecimento ao Professor Jose Matias Pereira pelo incentivo durante todo o curso, e a Professora Mariana Marlière Létti, pelas suas orientações para a elaboração deste trabalho. 
É triste pensar que a natureza fala e que o gênero humano não a ouve. (Victor Hugo) 


\section{RESUMO}

As necrópoles constituem um ramo de atividade que envolvem o ser humano sob a perspectiva ambiental como qualquer outro material de descarte, constituído de resíduos sólidos e produtor de materiais efluentes líquidos e gasosos. Levando em conta este aspecto, os cemitérios podem ser fontes de contaminação das águas superficiais e subterrâneas, por meio de substâncias orgânicas e inorgânicas, e microorganismos patogênicos presentes no líquido de decomposição de cadáveres, denominado de necrochorume. A percepção de que podemos destruir a natureza mesmo depois de mortos foi um incentivo para o desenvolvimento desta pesquisa, e de ampliar as discussões sobre a instalação de cemitérios e seus impactos ambientais. Ao abordar a legislação existente tanto para implementação como para funcionamento de necrópoles, as formas de atendimento das necessidades da população, assim como qual seria a melhor alternativa para o meio ambiente, foi possível verificar se as necrópoles constituem risco ambiental. A metodologia adotada foi a da pesquisa qualitativa, com um enfoque exploratório-descritivo, com o levantamento bibliográfico em artigos, livros e legislações acerca da atividade cemiterial no Brasil, e a realização de entrevista semi-estruturada junto a gestores de empresas que administram necrópoles, assim como visita a estes locais. Através da pesquisa efetuada pode-se concluir que se deve melhorar a monitoração, fiscalização, licenciamento e a operação das necrópoles existentes, assim como efetuar aprimoramentos na legislação federal. Através deste trabalho, apesar da escassez de material específico sobre o tema, foi constatado que os cemitérios que estejam adequados as resoluções CONAMA, tem menor possibilidade de apresentar risco ambiental do que os que não o fizeram. Apesar disso, através de um gerenciamento adequado, este risco pode ser considerado controlável se considerado o poder de contaminação de outras atividades.

Palavras-chave: Necrochorume. Cemitério. Impacto Ambiental. 


\section{LISTA DE ILUSTRAÇÕES}

Figura 1 - Foto de catacumbas ............................................................ 14

Figura 2 - Fotos de cemitérios horizontais............................................... 15

Figura 3 - Foto do cemitério vertical de Santos (SP) ....................................... 16

Figura 4 - Foto de cemitério parque ou jardim ............................................... 17

Figura 5 - Figura do processo de contaminação por necrochorume ......................26

Figura 6 - Figura do processo de contaminação por necrochorume ......................26 


\section{LISTA DE TABELA}

Tabela 1 - Atividades passíveis de causarem contaminação em cemitérios. .23 


\section{LISTA DE ABREVIATURAS E SIGLAS}

AAG - Agência Ambiental de Goiás

ADASA - Agência Reguladora de Águas e Saneamento do Distrito Federal

CETESB - Companhia de Tecnologia de Saneamento Ambiental de São Paulo

CONAMA - Conselho Nacional do Meio Ambiente

EIA - Estudo de Impacto Ambiental

EPI - Equipamento de Proteção Individual

PPRA - Programa de Prevenção de Riscos Ambientais

RIMA - Relatório de Impacto ao Meio Ambiente

SISNAMA - Sistema Nacional do Meio Ambiente

VISA - Superintendência de Vigilância Sanitária do Estado de Goiás 


\section{SUMÁRIO}

1 INTRODUÇÃO

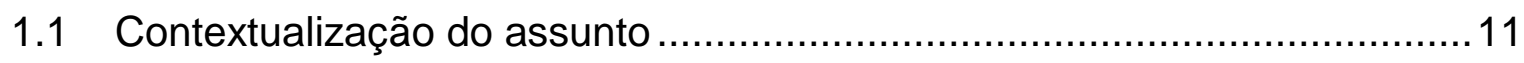

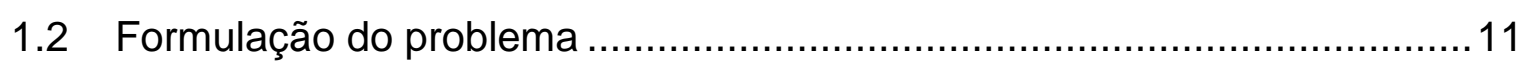

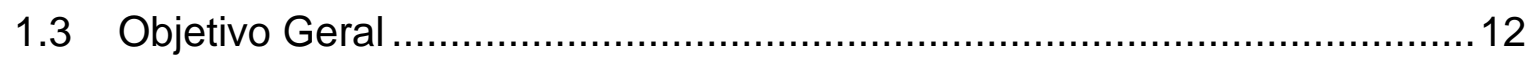

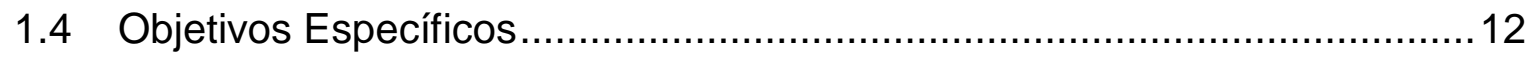

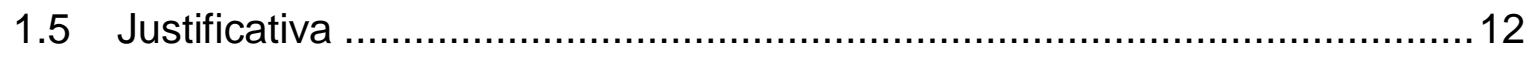

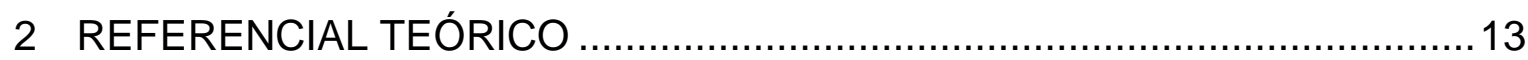

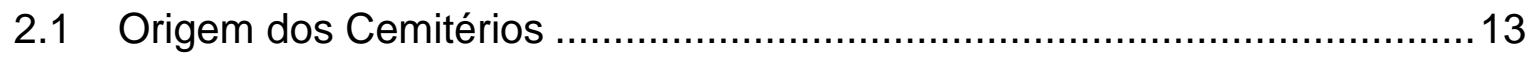

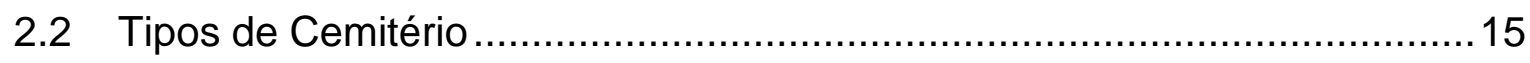

2.3 Legislação sobre Cemitério............................................................... 17

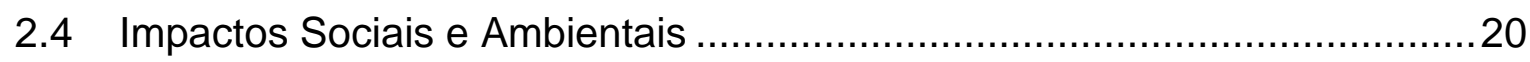

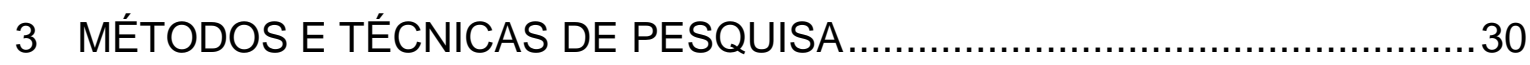

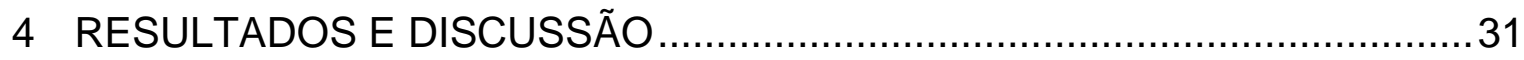

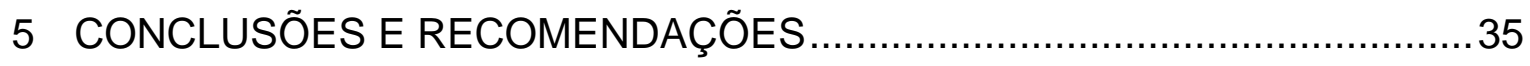

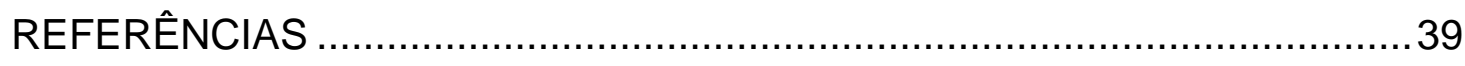

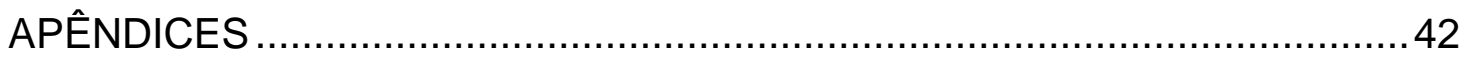




\section{INTRODUÇÃO}

\subsection{Contextualização do Assunto}

A palavra necrópole, sinônimo de cemitério, palavra esta que oriunda do grego koimetérion, "dormitório" do latim coemeteriu, designava primeiramente o lugar onde se dorme, quarto, dormitório. Posteriormente sob a influência do cristianismo, a palavra tomou o sentido de descanso após a morte. Tornaram-se uma necessidade da população, de acordo com seus costumes. Atualmente há uma grande demanda pelas questões ambientais, sendo que as necrópoles são pouco discutidas, mas também estas devem ter regulação ambiental para o seu funcionamento. Tenho como objetivo verificar a respeito da instalação de necrópoles, normalmente afastados dos centros das cidades, mas com o crescimento desordenado das cidades muitos foram engolidos por áreas residenciais e comerciais. Os cemitérios podem representar risco ao meio ambiente, pois na ocasião do óbito, o corpo sob a perspectiva ambiental é tido como qualquer outro material de descarte, constituído de resíduos sólidos e produtor de materiais efluentes líquidos e gasosos.

A dimensão dos impactos ambientais causados pela morte de seres humanos está diretamente relacionada com o problema da grande densidade populacional global. Assim as necrópoles podem ser fontes de contaminação das águas superficiais e subterrâneas, por meio de substâncias orgânicas e inorgânicas, e microorganismos patogênicos presentes no líquido de decomposição de cadáveres, denominado de necrochorume. Com o intuito de verificar se os cemitérios constituem efetivamente risco ambiental, e em face da necessidade da sociedade por este tipo de empreendimento, pretendo realizar um estudo através de pesquisa bibliográfica e de obtenção de informações, através de entrevista junto a gestores de cemitérios da região metropolitana do Distrito Federal.

\subsection{Formulação do problema}

Constituem as necrópoles risco ambiental? 


\subsection{Objetivo Geral}

Abordar a legislação e as questões ambientais de funcionamento e implantação de uma necrópoles.

\subsection{Objetivos Específicos}

- Levantar a legislação existente tanto para implementação/funcionamento de uma necrópoles como a legislação ambiental existente quanto ao tema;

- Levantar as possíveis formas de atendimento das necessidades da população e seu impacto ambiental;

- Identificar a melhor alternativa para o meio ambiente e que satisfaça às necessidades da população.

\subsection{Justificativa}

As necrópoles constituem um ramo de atividade que envolvem o ser humano sob a perspectiva ambiental como material de descarte, constituído de resíduos sólidos e produtor de materiais efluentes líquidos e gasosos. Este tipo de construção, monumentos à memória dos que morreram, adquiriu certa condição de inviolabilidade quanto a pesquisa científica nos seus diferentes aspectos, sendo poucas as publicações acerca do tema. A percepção de que podemos destruir a natureza mesmo depois de mortos incentivou-me a desenvolver esta pesquisa para ampliar as discussões sobre a instalação de cemitérios e seus impactos ambientais. 


\section{REFERENCIAL TEÓRICO}

\subsection{Origem dos Cemitérios}

A palavra cemitério, do grego koimeterion "dormitório" do latim coemeteriu, era a designação a princípio, do lugar onde se dorme, quarto, dormitório. Foi com a influência do cristianismo que o termo tomou o sentido de descanso após a morte. $O$ cemitério também é conhecido como necrópole, carneiro, sepulcrário, campo-santo, e vários eufemismos, como "cidade dos pés juntos" e "última morada". A palavra teve uma evolução semântica ao longo do tempo, impondo-se definitivamente na língua francesa, desde o século XVI. Em inglês o emprego da palavra cemetery na linguagem corrente só aparece muito depois. Churchyard ou graveyard só foram substituídas por cemetery no século XIX e para designar, por oposição, uma outra forma de cemitério, o rural cemetery.

Cronológicamente as edificações dos cemitérios na antiguidade foram as catacumbas cristãs, como ilustra a Figura 1. Eram nas paredes das galerias subterrâneas que se faziam as tumbas para enterrar os mortos e também o local utilizado pelos primeiros cristãos para se reunirem secretamente no período em que ainda eram perseguidos. O sepultamento em terra tinha um significado importante, pois a perspectiva religiosa levava a preservação dos lugares considerados santos, e o cemitério passou a ser considerado um desses espaços. Isto se efetuou em face da Fé dos cristãos, podendo ser identificada como elemento responsável pela mudança de comportamento de muitas pessoas em relação à prática do enterramento. Outro elemento que também contribuiu para que o incentivo aumentasse foi a valorização do culto aos mártires, concedido por parte da instituição eclesiástica, que atraía para seus túmulos pessoas de outros lugares. Diante disto, ser enterrado próximo a esses túmulos significava proteção para o momento do despertar, tendo esse pensamento fundamentado na crença de que os santos possuíam lugar garantido no paraíso. Daí também surgiu a prática de, em muitos desses locais, edificar basílicas, que além da sua função religiosa também serviam para alojar os mortos. Esta prática de enterrar em solo sagrado foi se ampliando ao longo do medievo e muitos cemitérios em espaços abertos foram sendo deixados de lado, passando a se localizarem próximos às igrejas. 
Figura 1: Foto de catacumbas

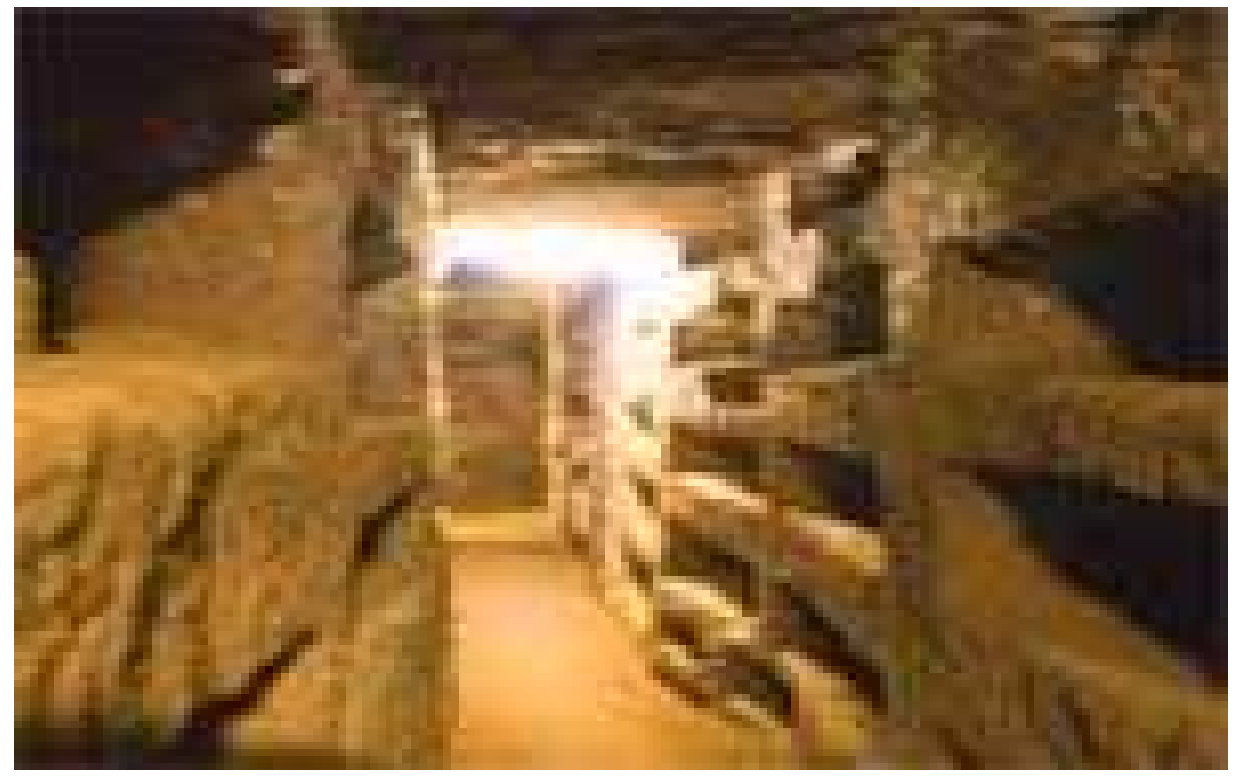

Fonte: http://www.suapesquisa.com/o_que_e/catacumbas.htm

Todavia, transformações significativas dos cemitérios ocorreram a partir da primeira metade do século XVIII, quando foram levados para fora dos jardins e do interior das igrejas. Com isto, os mortos passaram a ser velados e enterrados no circuito íntimo da família. Esta postura veio acompanhada pela redefinição da noção de ritual e da intensificação para individualizar a sepultura, antes privilégio da nobreza e do clero. Também novos critérios médicos foram desenvolvidos, pois a grande quantidade de túmulos, no convívio com os vivos, preocupava os higienistas, que passaram a alertar a população para o grande perigo dessa proximidade. Foram as preocupações de parte dos médicos que acusavam os problemas causados pelos corpos que estavam em processo de decomposição, por intermédio do mau-cheiro, chorume e outros odores desagradáveis, que segundo os médicos tinham influência na saúde humana, que fundamentaram a nova maneira de pensar e agir. Emanavam das sepulturas vapores ou fumaça que transformavam o ar e que interferiam diretamente na saúde do ser humano, causando alguns tipos de doenças. Por esta nova perspectiva, a presença do morto se tornava inconveniente e representava perigo aos vivos. De lá para cá os cemitérios tem, cada vez mais, sido pensados como espaços que devem ser isolados da presença humana e, estéticamente, tornados mais bonitos. 


\subsection{Tipos de Cemitério}

Existem dois tipos de cemitério: o convencional, com sepulturas na posição horizontal, como ilustra a Figura 2, e o vertical que é um edifício, ilustrado na Figura 3, com vários níveis, pelos quais se distribuem os lóculos, cavidades onde são colocados os corpos. Este tipo de cemitério é utilizado principalmente em cidades ou países pequenos, mas com alta densidade demográfica. Dentre os tipos convencionais, os cemitérios tipo parque, ilustrado na Figura 4, são os mais comuns e representam uma alternativa entre a ostentação suntuosa de túmulos e mausoléus e a frieza dos cemitérios verticais. Neles a beleza da natureza é fator predominante. Os jardins, gramados e plantas são bem cuidados, proporcionando um ambiente de paz e serenidade. O cemitério vertical tem como finalidade solucionar o problema de escassez de área para sepultamento nas cidades de maior densidade demográfica. É um edifício dotado de infra-estrutura para oferecer os mesmos serviços do cemitério convencional e pode ter cerca de 4 mil jazigos e 2 mil ossários perpétuos. No cemitério vertical os jazigos são distribuídos em níveis e dotados de sistema duplo para ventilação e captação de gases.

Figura 2: Fotos de cemitérios horizontais

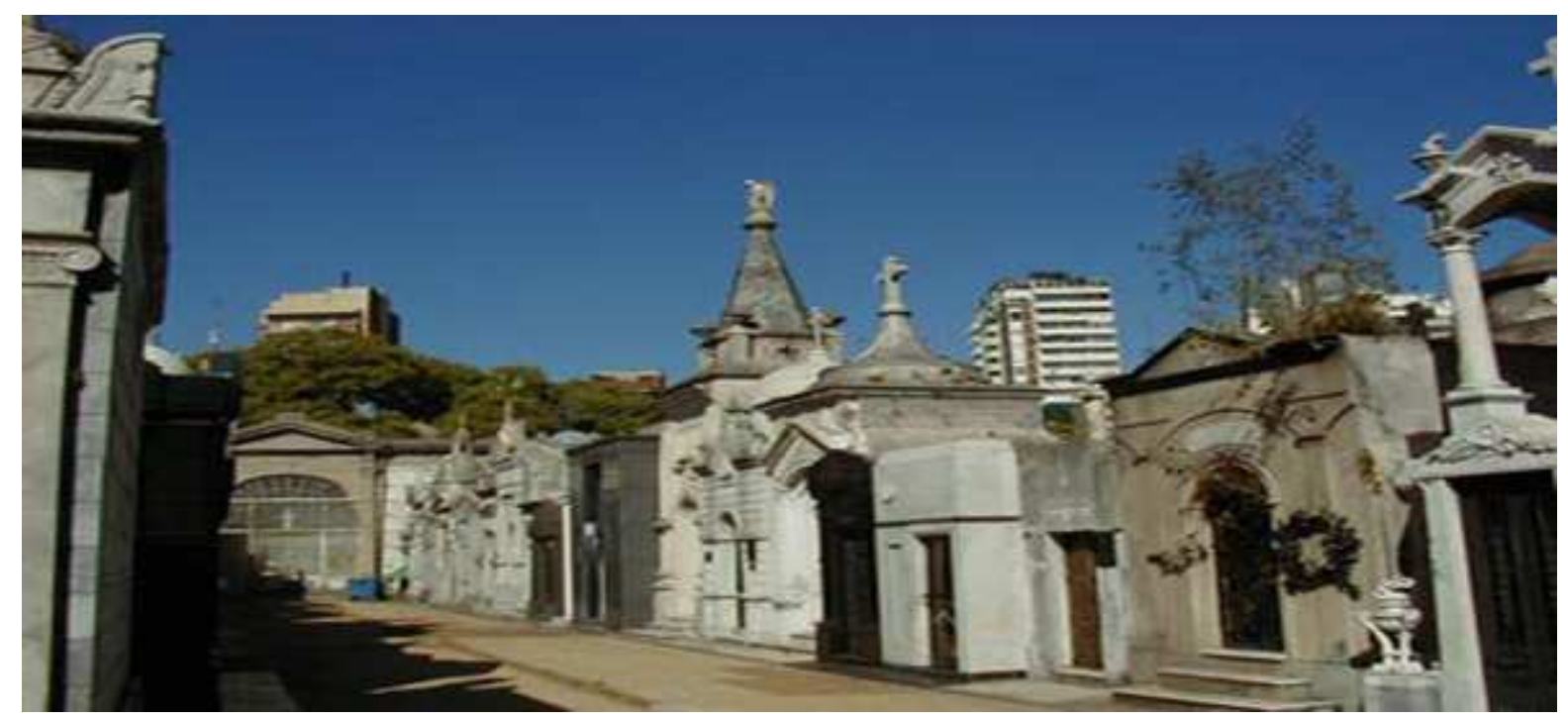




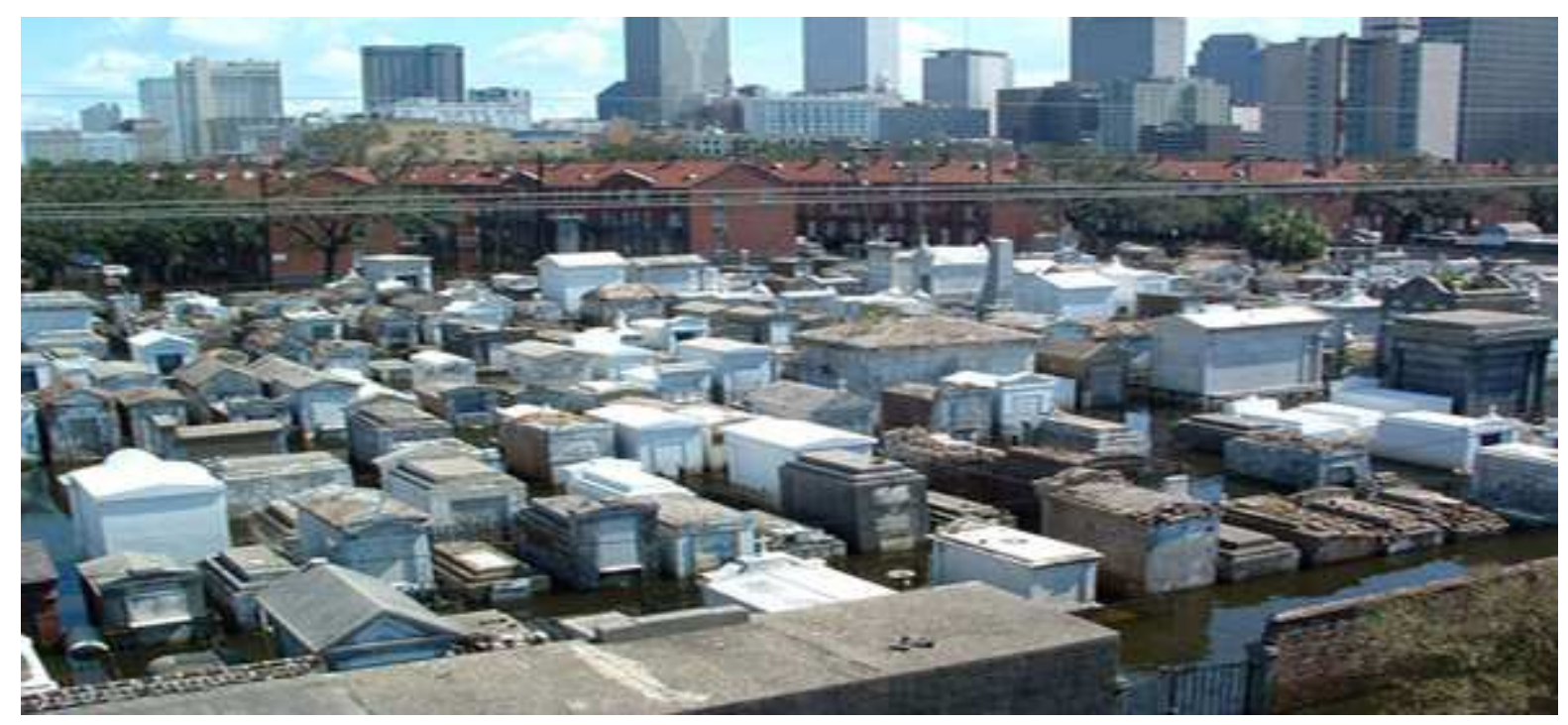

Fonte: http://tvcanal7.blogspot.com/2010/10/top-10-cemiterios-que-devem-ser.html

Figura 3: Foto do cemitério vertical de Santos (SP)

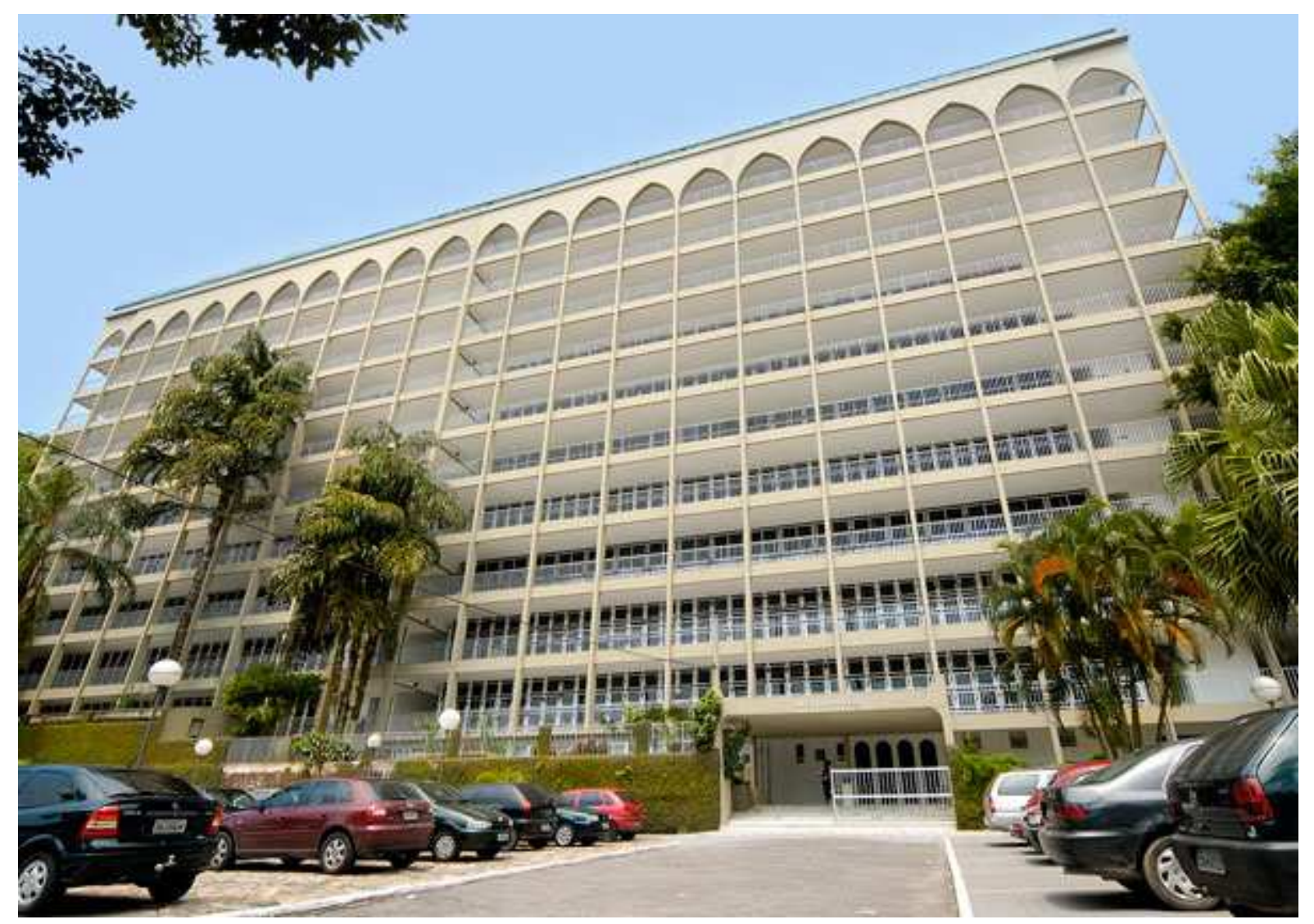

Fonte: http://www.memorialcemiterio.com.br/fotos.html 
Figura 4: Foto de cemitério parque ou jardim

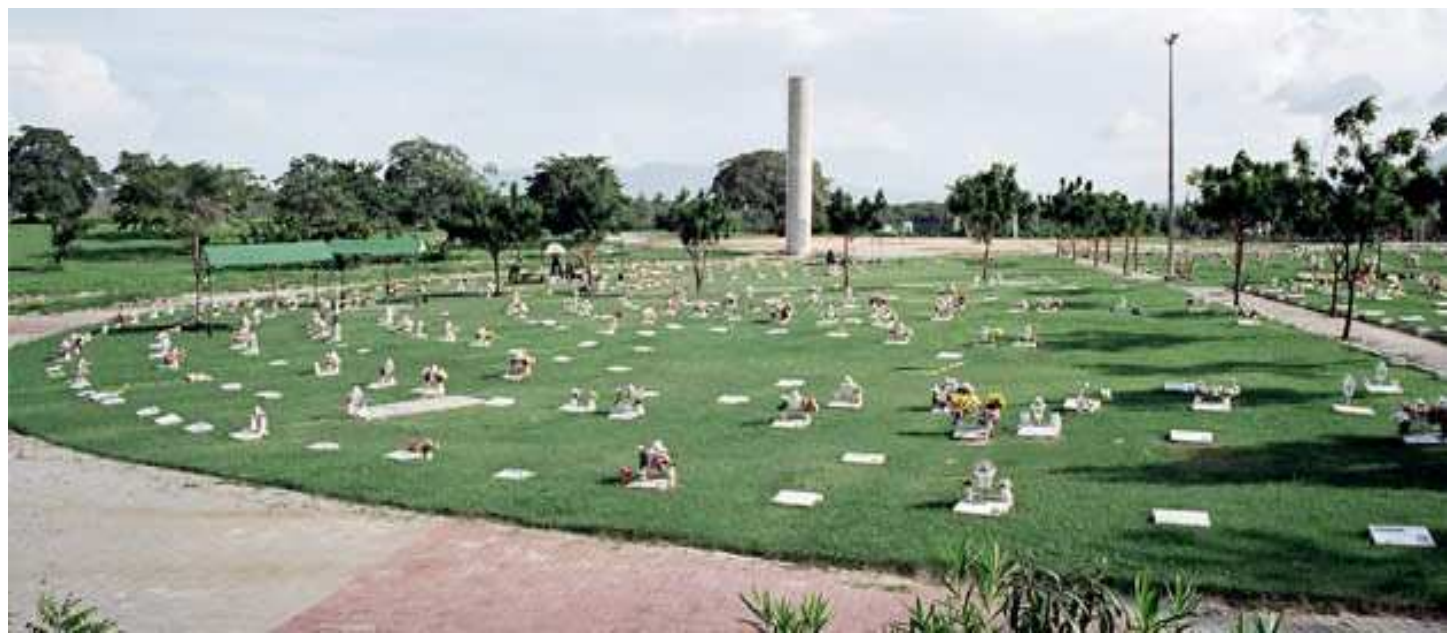

Fonte: http://www.parquedasaudade.com.br/galeriadefotos.html

\subsection{Legislação sobre Cemitério}

O ramo econômico de serviços funerários segue legislação e normas específicas estabelecidas para o setor. De acordo com Andrade (2007, p. 45), em 1987, o Brasil foi o primeiro país do mundo a ter normas de procedimentos ambientais voltadas para cemitérios. O problema foi levantado na Companhia de Tecnologia de Saneamento Ambiental de São Paulo, que editou uma norma de procedimento interno CETESB chamada L1040, revisada e atualizada em 1999. Foi a primeira norma que foi feita no mundo sobre cemitério, porque isso é problema de nações em desenvolvimento e subdesenvolvidas.

Em 2003, a preocupação com o impacto ambiental dos cemitérios chamou a atenção do Governo Federal. A esfera municipal é a responsável pela formulação de leis locais, e a determinação de normas é feita por órgãos ambientais da administração publica que compõem o Sistema Nacional do Meio Ambiente (SISNAMA), sendo a Resolução do Conselho Nacional do Meio Ambiente CONAMA, ํㅡ 335/2003, de 03 de abril de 2003, o marco regulatório ambiental para o setor. A resolução oㅡ 335 dispõe acerca do licenciamento ambiental de cemitérios 
horizontais e verticais a serem implantados no Brasil, tendo os órgãos estaduais a obrigação de licenciar e fiscalizar a implantação de novos cemitérios.

De acordo com Silva (2008),

" aos cemitérios já existentes foi dado um prazo de dois anos após aquela
data, para se adequarem as exigências junto aos órgãos ambientais
competentes, inclusive no que se refere a recuperação da área
contaminada e a indenização de possíveis vitimas da contaminação
ambiental. "(SILVA, 2008,p.28)

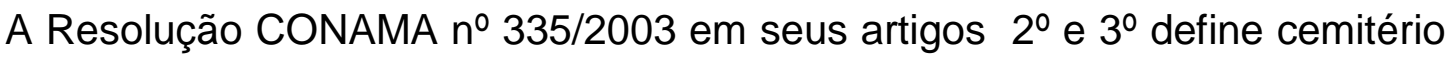
e seus diversos serviços:

Art. $1^{\circ}$ - Os cemitérios horizontais e os cemitérios verticais, doravante denominados cemitérios, deverão ser submetidos ao processo de licenciamento ambiental, nos termos desta Resolução, sem prejuízo de outras normas aplicáveis à espécie. Art. 2ํ - Para efeito desta Resolução serão adotadas as seguintes definições: I-cemitério: área destinada a sepultamentos;

a) cemitério horizontal: é aquele localizado em área descoberta compreendendo os tradicionais e o do tipo parque ou jardim;

b) cemitério parque ou jardim: é aquele predominantemente recoberto por jardins, isento de construções tumulares, e no qual as sepulturas são identificadas por uma lápide, ao nível do chão, e de pequenas dimensões;

c) cemitério vertical: é um edifício de um ou mais pavimentos dotados de compartimentos destinados a sepultamentos; e

d) cemitérios de animais: cemitérios destinados a sepultamentos de animais. II - sepultar ou inumar: é o ato de colocar pessoa falecida, membros amputados e restos mortais em local adequado;

III - sepultura: espaço unitário, destinado a sepultamentos;

IV - construção tumular: é uma construção erigida em uma sepultura, dotada ou não de compartimentos para sepultamento, compreendendo-se:

a) jazigo: é o compartimento destinado a sepultamento contido;

b) carneiro ou gaveta: é a unidade de cada um dos compartimentos para sepultamentos existentes em uma construção tumular; e

c) cripta: compartimento destinado a sepultamento no interior de edificações, templos ou suas dependências.

V - lóculo: é o compartimento destinado a sepultamento contido no cemitério vertical; VI - produto da coliqüação: é o líquido biodegradável oriundo do processo de 
decomposição dos corpos ou partes;

VII - exumar: retirar a pessoa falecida, partes ou restos mortais do local em que se acha sepultado;

VIII - reinumar: reintroduzir a pessoa falecida ou seus restos mortais, após exumação, na mesma sepultura ou em outra;

IX - urna, caixão, ataúde ou esquife: é a caixa com formato adequado para conter pessoa falecida ou partes;

X - urna ossuária: é o recipiente de tamanho adequado para conter ossos ou partes de corpos exumados;

XI - urna cinerária: é o recipiente destinado a cinzas de corpos cremados;

XII - ossuário ou ossário - é o local para acomodação de ossos, contidos ou não em urna ossuária;

XIII - cinerário: é o local para acomodação de urnas cinerárias;

XIV - columbário: é o local para guardar urnas e cinzas funerárias, dispostos horizontal e verticalmente, com acesso coberto ou não, adjacente ao fundo, com um muro ou outro conjunto de jazigos;

$X V$ - nicho: é o local para colocar urnas com cinzas funerárias ou ossos; e

XVI - translado: ato de remover pessoa falecida ou restos mortais de um lugar para outro.

Em 28 de março de 2006, foi promulgada a Resolução do Conselho Nacional do Maio Ambiente - CONAMA no 368, que altera alguns dispositivos nos artigos $3^{\circ} \mathrm{e}$ $5^{\circ}$ da Resolução oㅜ 335. No artigo 3ㄴ, mudou-se a redação do capítulo 1 vigorando a seguinte: É proibida a instalação de cemitérios em Áreas de Preservação Permanente ou em outras que exijam desmatamento de Mata Atlântica primária ou secundária, em estágio médio ou avançado de regeneração, em terrenos predominantemente cársticos, que apresentam cavernas, sumidouros ou rios subterrâneos, bem como naquelas que tenham seu uso restrito pela legislação vigente, ressalvadas as exceções legais previstas. Ainda no artigo $3^{\circ}$, fica revogado o inciso III, do $\S 3^{\circ}$. E no artigo 5º, o inciso I passou a vigorar a seguinte redação: $O$ nível inferior das sepulturas deverá estar a uma distância de pelo menos um metro e meio acima do mais alto nível do lençol freático, medido no fim da estação das cheias; acrescentou-se ainda o capítulo $1^{\circ}$ e seus três incisos que complementam os incisos I e IV da resolução ํㅜ 335 , e o capítulo 2ํㅜ I - a área prevista para a 
implantação do cemitério deverá estar a uma distância segura de corpos de água, superficiais e subterrâneos, de forma a garantir sua qualidade, de acordo com estudos apresentados e a critério do órgão licenciador;

II - o perímetro e o interior do cemitério deverão ser providos de um sistema de drenagem adequado e eficiente, destinado a captar, encaminhar e dispor de maneira segura o escoamento das águas pluviais e evitar erosões, alagamentos e movimentos de terra;

III - o subsolo da área pretendida para o cemitério deverá ser constituído por materiais com coeficientes de permeabilidade entre 10-5 e 10-7 cm/s, na faixa compreendida entre o fundo das sepulturas e o nível do lençol freático, medido no fim da estação das cheias. Para permeabilidades maiores, é necessário que o nível inferior dos jazigos esteja dez metros acima do nível do lençol freático.

$\S 2^{\circ}$ - A critério do órgão ambiental competente, poderão ser solicitadas informações e documentos complementares em consonância com exigências legais específicas de caráter local.

Posteriormente, em 17 de novembro de 2008, foi editada a Resolução do Conselho Nacional do Maio Ambiente - CONAMA no 402, que altera os dispositivos dos artigos $11^{\circ}$ e $12^{\circ}$ da Resolução $n^{\circ} 335$. No artigo $11^{\circ}$, passou a vigorar a seguinte redação: Os órgãos estaduais e municipais de meio ambiente deverão estabelecer até dezembro de 2010 critérios para adequação dos cemitérios existentes em abril de 2003. No artigo $12^{\circ}$, foi estabelecido que : O Plano de Encerramento das atividades deverá constar do processo de licenciamento ambiental, nele incluindo medidas de recuperação da área atingida e indenização de possíveis vítimas.

\subsection{Impactos Sociais e Ambientais}

De acordo com Link (1984, p.284),

"o processo de uso e ocupação do solo é o rebatimento espacial do
sistema de produção de bens materiais e de desenvolvimento cultural dos
homens. Tal sistema tem como objetivo satisfazer as necessidades básicas
do ser humano. Tal rebatimento espacial que visava a criação de um
habitat para o homem, sempre se constituiu em uma forma de dominar a
natureza para possibilitar a sua própria sobrevivência e nunca se realizou
sem problemas, aos quais modernamente denominamos de problemas
ambientais. O que mudou nesse aspecto, ao longo do tempo, foram a
dimensão e a escala desta problemática ambiental. Por outro lado mudou
consideravelmente em função da forma como hoje se realiza esse 
rebatimento espacial e suas conseqüências sobre o meio ambiente. A atuação de poucos provoca efeitos sobre muitos. "(LINK, 1984, p.284)

A aceleração do processo de desenvolvimento gerou distorções acentuadas na utilização da natureza, o atendimento as necessidades básicas do homem transformou-se em aumento dos lucros e o conseqüente desenvolvimento industrial e urbano gerou poluição e detritos que representam uma ameaça não desprezível. A partir daí nasceu um interesse intenso pelos temas ambientais, que no início se fixaram nos aspectos de contaminação. Nos países em desenvolvimento o conceito de meio ambiente deve ser ampliado e a solução de seus problemas tem caráter sócio-econômico e político mais que tecnológico, visto que as questões ambientais decorrem principalmente do subdesenvolvimento, por meio de problemas de saneamento, deficiência dos assentamentos humanos, carência de habitações e equipamentos comunitários, deficiências de nutrição, destruição de florestas e perda de solos, destruição ou má exploração de recursos naturais. Nesses países, os problemas ambientais e sociais se confundem ou superpõe.

$\mathrm{Na}$ implantação de cemitérios, os municípios, na maioria das vezes, escolhem terrenos de baixo ou nenhum valor de mercado. Na maior parte, terrenos grandes e íngremes em regiões à época da implantação, afastadas do centro da cidade, ignorando a formação geológica e hidrogeológica. Assim, as necrópoles com localização e manejos inadequados podem se tornar focos geradores de impacto ambiental.

Segundo Andrade (2007, p.21) o Professor e hidrogeólogo Dr. Leziro Marques Silva, através de pesquisa realizada nos últimos 35 anos, em mais de 900 cemitérios no Brasil e exterior, constatou que desse universo, dos cemitérios públicos pesquisados, de todos os municípios, $75 \%$ apresentavam problemas de ordem tanto ambiental quanto sanitária. Para Leziro, o cadáver humano pode por em risco a saúde dos vivos porque:

\footnotetext{
" o necrochorume é vertido pela matéria orgânica em decomposição, ele é rico em nutrientes que proliferam uma assembléia de vírus e bactérias, inclusive as bactérias patogênicas, que são as causadoras da maior parte dos óbitos. Se esse necrochorume escapa do túmulo, entra na circulação do lençol freático. Se você tem no caminho desse lençol freático um poço escavado, uma captação, uma fonte, uma pessoa que inadvertidamente consuma essa água, e se ela tiver a imunidade natural baixa, ela pode ser acometida por uma dessas doenças infecto-contagiosas "(ANDRADE, 2007,p.21)
} 
De acordo com o Professor e Mestre em Geociências e Meio Ambiente da UNESP, Robson Willians da Costa Silva (2008, p.27), as atividades de sepultamento de cadáveres geram fontes poluidoras do meio físico, sendo assim devem ser consideradas como uma atividade - aspecto - impacto ambiental.

Os cemitérios nunca foram incluídos nas listas de fontes tradicionais de contaminação ambiental, apesar da existência de alguns relatos históricos em Berlim e Paris na década de 70, constatando que a causa de epidemias de febre tifóide estava diretamente ligada ao posicionamento a jusante de fontes de água, como aqüíferos freáticos e nascentes, dos cemitérios. No Brasil, são inúmeros os casos de áreas contaminadas divulgados ao público nos últimos anos.

$\mathrm{Na}$ tentativa de resolução do problema, a Companhia de Tecnologia de Saneamento Ambiental (CETESB), órgão responsável pelo controle ambiental no estado de São Paulo, com a cooperação técnica do órgão alemão Deutsche Gesellschaft Für Technishe Zusammenarbeit (GTZ), elaborou em 2001 o "Manual de Investigação de Áreas Contaminadas". Esse manual se tornou referência no âmbito de gerenciamento de áreas contaminadas no Brasil, mas não consta em seu capítulo 3 entitulado - "Identificação de Áreas Contaminadas", a atividade de sepultamento de cadáveres como atividade passível de causar contaminação.

Mesmo que a atividade de sepultamento não se enquadre literalmente como atividade industrial ou comercial, podem ocorrer vazamentos de substâncias passíveis de causar danos ao solo e águas subterrâneas, visto que nessa atividade se manuseiam resíduos biológicos - os cadáveres.

Ainda conforme Silva (2008, p.27), uma área contaminada pode ser definida como uma área onde há comprovadamente poluição ou contaminação, causada pela introdução de substâncias ou resíduos que nela tenham sido depositados, acumulados, armazenados, enterrados ou infiltrados de forma planejada, acidental ou até mesmo natural (CETESB, 2001).

A CETESB (2001) aponta alguns critérios que devem ser levantados para que uma área possa ser considerada como potencialmente contaminada. A Tabela 1 apresenta as características das atividades passíveis de causarem contaminação encontrada em cemitério. 
Tabela 1: Características de atividades passíveis de causarem contaminação em cemitérios.

\begin{tabular}{|l|l|}
\hline CARACTERÍSTICAS & OCORRÊNCIA \\
\hline $\begin{array}{l}\text { Existência de processos produtivos que } \\
\text { possam causar contaminação do solo e } \\
\text { águas subterrâneas }\end{array}$ & \\
\hline $\begin{array}{l}\text { Presença de substâncias que possuam } \\
\text { potencial para causar danos aos bens a } \\
\text { proteger via solos e águas subterrâneas }\end{array}$ & Pode ocorrer em áreas de cemitério \\
\hline $\begin{array}{l}\text { Atividade industrial ou comercial que } \\
\text { apresente histórico indicando manuseio, } \\
\text { armazenamento ou disposição inadequada } \\
\text { de matérias prima, produtos e resíduos }\end{array}$ & Pode ocorrer em áreas de cemitério \\
\hline $\begin{array}{l}\text { Atividade industrial ou comercial que } \\
\text { apresente histórico indicando a ocorrência } \\
\text { de acidentes ou vazamentos }\end{array}$ & Pode ocorrer em áreas de cemitério \\
\hline $\begin{array}{l}\text { Atividade industrial ou comercial que } \\
\text { apresente histórico de geração de áreas } \\
\text { suspeitas de contaminação ou de áreas } \\
\text { contaminadas }\end{array}$ & Pode ocorrer em áreas de cemitério \\
\hline
\end{tabular}

Fonte: Silva (2008, p. 27)

De acordo com o Professor Pesquisador do Instituto de Geociências da Universidade de São Paulo - USP, Alberto Pacheco (2000, p.13), os cemitérios são um risco potencial para o ambiente. No Brasil, quase sempre, a implantação dos mesmos tem sido feita em terrenos de baixo valor imobiliário ou com condições geológicas, hidrogeológicas e geotécnicas inadequadas. Este cenário poderá propiciar a ocorrência de impactos ambientais (alterações físicas, químicas e biológicas do meio onde está implantado o cemitério) e fenômenos conservadores, como a saponificação. Os impactos ambientais são mais freqüentes nos cemitérios públicos, os quais, em geral, são implantados e operados de forma negligente.

Os impactos ambientais são classificados em duas categorias: o impacto físico primário - que ocorre quando há contaminação das águas subterrâneas de menor profundidade (aqüífero freático) e, excepcionalmente, das águas superficiais; e o impacto físico secundário - que ocorre quando há presença de cheiros 
nauseabundos na área interna dos cemitérios provenientes da decomposição dos cadáveres. Segundo os tanatólogos (estudiosos da morte), os gases funerários resultantes da putrefação dos cadáveres são o gás sulfídrico, os mercaptanos, o dióxido de carbono, o metano, o amoníaco e a fosfina. Os dois primeiros são os responsáveis pelos maus odores. O vazamento destes gases para a atmosfera de forma intensa deve-se a má confecção e manutenção das sepulturas (covas simples) e dos jazigos (construções de alvenaria ou concreto, enterradas ou semienterradas).

A decomposição ou putrefação de um corpo compreende várias fases, das quais a fase humorosa ou coliquativa ( dissolução pútrida das partes moles do corpo) é a mais preocupante em termos ambientais. É nesta fase (duração de dois ou mais anos) que ocorre a liberação do líquido humoroso (liquame, putrilagem), também conhecido por necrochorume, por analogia com o chorume, líquido proveniente da decomposição bioquímica dos resíduos orgânicos dispostos nos aterros sanitários. No caso de pessoas que morrem com doenças infectocontagiosas, para além de outros microorganismos, podem estar presentes no necrochorume os patogênicos, como bactérias e vírus, agentes transmissores de doenças ( febre tifóide, paratifóide, hepatite infecciosa e outras) responsáveis pela causa mortis. Os especialistas são unânimes que o perigo do necrochorume é devido aos microorganismos patogênicos, aos seus riscos infecciosos. Pela ação das águas superficiais e das chuvas infiltradas nas sepulturas ou pelo contato dos corpos com as águas subterrâneas (aqüífero freático), o necrochorume pode atingir e contaminar estas águas. Se as mesmas fluírem para a área externa do cemitério e forem captadas através de poços escavados, as populações que vivem no entorno, poderão correr sérios riscos de saúde.

Segundo Pacheco (2000, p.14) a saponificação (fenômeno que faz com que o cadáver permaneça conservado por mais tempo), também conhecida por adipocera (gordura de aspecto céreo), ocorre quando o corpo é sepultado em ambiente úmido, pantanoso. O solo argiloso, poroso, impermeável ou pouco permeável, quando saturado de água, facilita a saponificação. Logo, este solo não é recomendável para sepultamentos. Em geral a formação da adipocera leva de cinco a seis meses após a morte e o corpo saponificado fica com aspecto untoso, com odor de queijo rançoso. O fenômeno é comum nos cemitérios brasileiros, tendo como causa a invasão das sepulturas por águas superficiais e subterrâneas. Enquanto persistir a 
causa, o corpo ficará saponificado. Esta situação cria sérias dificuldades no que tange a reutilização das sepulturas. O problema poderá ser resolvido mudando o corpo para uma sepultura seca ou cremando o mesmo.

De acordo com Silva $(2009$, p.28) a principal causa de poluição dos cemitérios é a eliminação do necrochorume pelos cadáveres, particularmente, no primeiro ano do sepultamento. O necrochorume pode veicular, além de micro-organismos oriundos do cadáver, restos ou resíduos de tratamentos químicos hospitalares (quimioterapia, por exemplo) e os compostos decorrentes da decomposição da matéria orgânica. Esses contaminantes incorporados ao fluxo de necrochorume são prejudiciais ao solo e às águas subterrâneas.

Segundo Silva (2009), "..os compostos orgânicos liberados no processo de decomposição dos
cadáveres aumentam a atividade microbiana no solo sob a área de
sepultamentos. Nessas áreas, há aumento da condutividade elétrica, pH,
alcalinidade e dureza da solução do solo, devido à presença de compostos
de nitrogênio e fósforo e de diversos sais $\left(\mathrm{Cl}^{-}, \mathrm{HCO}_{3}, \mathrm{Ca}^{+2}, \mathrm{Na}^{+}\right)$. Ocorre
também a presença de óxidos metálicos $(\mathrm{Ti}, \mathrm{Cr}, \mathrm{Cd}, \mathrm{Pb}, \mathrm{Fe}, \mathrm{Mn}, \mathrm{Ni}$, entre
outros) lixiviados dos adereços das urnas mortuárias e de patógenos
associados a mortes por doenças infecto-contagiosas. "(SILVA, 2009,p.28)

Conforme Silva (2009, p. 27) os corpos, mesmo em caixões, podem sofrer, sob certas condições ambientais, fenômenos transformativos destrutivos, como autólise e putrefação, ou conservativos, como saponificação. A autólise é iniciada logo que cessa a vida: as células deixam de receber oxigênio e de trocar nutrientes, e passam a ser dissolvidas por enzimas do próprio corpo. Em seguida vem a putrefação, ou seja, a decomposição de tecidos e órgãos por bactérias e outros micro-organismos. A ocorrência desses fenômenos depende de fatores intrínsecos e extrínsecos. Os primeiros estão associados ao próprio cadáver: idade, constituição física e causa da morte. Os segundos, ao ambiente de sepultamento: temperatura, umidade, aeração, constituição mineral do solo, permeabilidade e outros. O necrochorume é o principal responsável pela poluição ambiental causada pelos cemitérios, processo que pode ser visualizado por meio das Figuras 5 e 6 . É um líquido viscoso, de cor castanho-acinzentada, com $60 \%$ de água, $30 \%$ de sais minerais e $10 \%$ de substâncias orgânicas degradáveis. Apresenta variado grau de patogenicidade, por causa da presença de vírus, bactérias e outros agentes causadores de doenças. Cada quilo de massa corpórea do cadáver gera 0,6 litro de necrochorume. Estão presentes ainda no necrochorume metais pesados, 
provenientes dos adereços dos caixões, além de formaldeído e metanol, utilizados na embalsamação dos corpos. O uso, comum atualmente, da tanatopraxia - técnica de maquiar partes do falecido com cosméticos, corantes, enrijecedores e outros produtos - também é fonte de substâncias para o necrochorume, que pode ainda conter resíduos de tratamentos químicos hospitalares (de medicamentos, por exemplo). Os compostos orgânicos degradáveis liberados no processo de decomposição dos corpos estimulam a atividade microbiana no solo sob áreas de sepultamentos. Também aumentam, no solo, o teor de compostos de nitrogênio e fósforo e o de sais (o que eleva a condutividade elétrica) e o índice de acidez.

Figura 5: Processo de contaminação do lençol freático por necrochorume

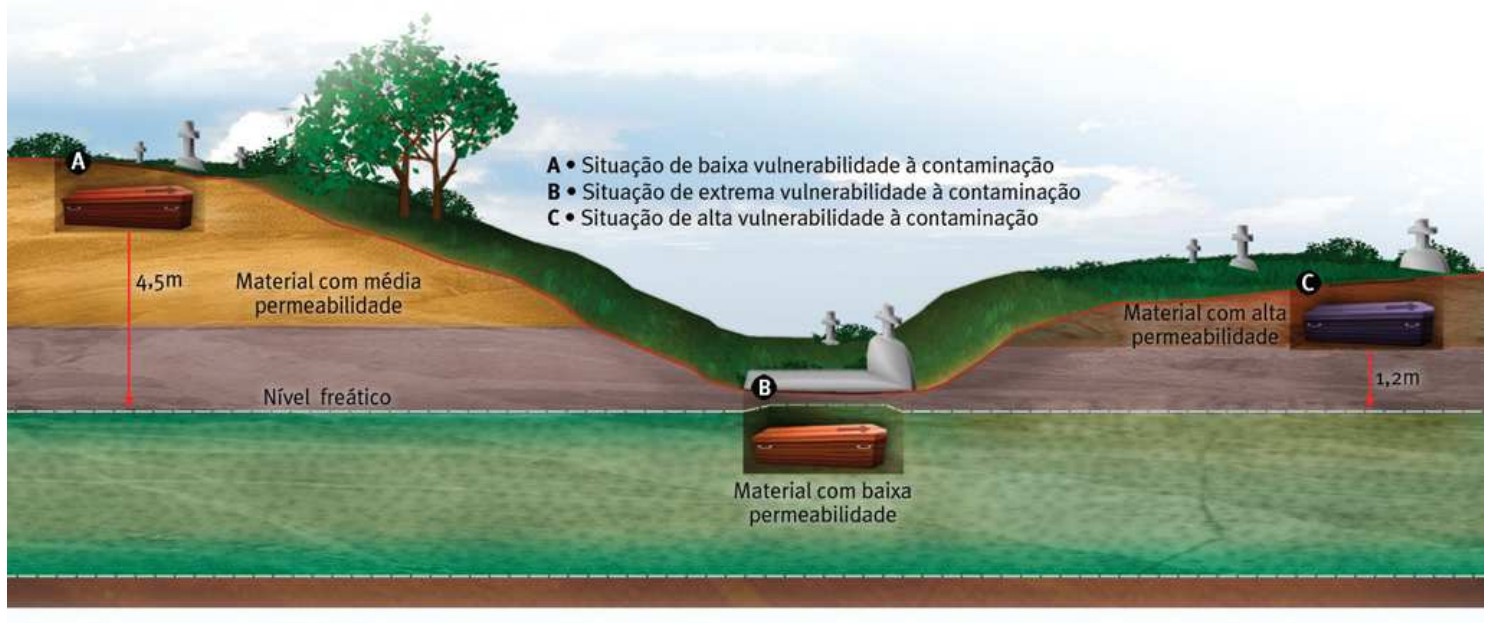

Fonte: Silva (2009, p.29)

Figura 6: Processo de contaminação do lençol freático por necrochorume

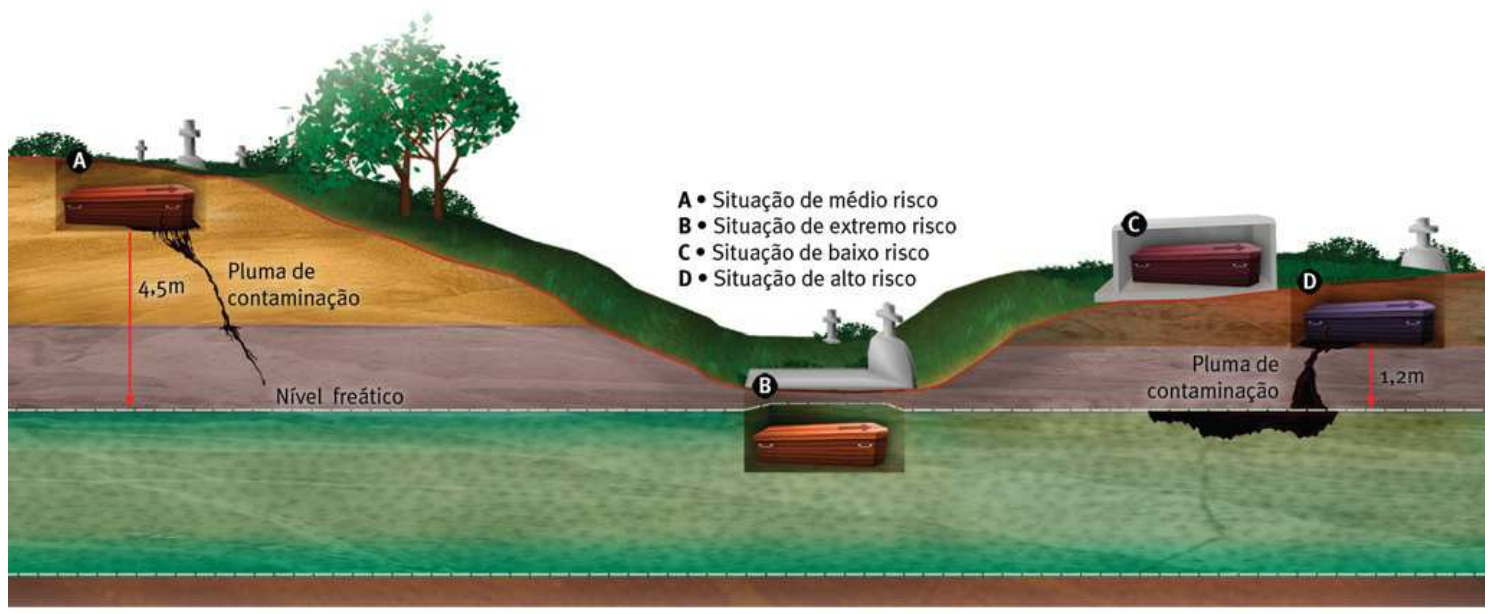

Fonte: Silva (2009, p.29) 
De acordo com Machado (2006, p.135), construir um cemitério requer, primeiramente, detalhado planejamento urbano. Caso não haja um prévio estudo de impacto ambiental corre-se o risco de haver também problemas estéticos e até mesmo de saúde pública. Atualmente, são raros os administradores públicos que se preocupam com o problema da localização e manutenção das necrópoles. Infelizmente, o problema é colocado em segundo plano. Fatores de ordem religiosa, psicológica e político-administrativa impedem a atuação efetiva dos governos locais.

Grande polêmica é a instalação de fornos crematórios que, muitas vezes, apesar de serem ambientalmente viáveis são evitados por não serem aprovados por algumas religiões e culturas vigentes. Estas, deveras, não podem ser ignoradas. São valores morais e espirituais arraigados também na sociedade Brasileira. Sendo assim, a inumação ainda é a regra no Brasil e, por isso, ao se escolher um determinado sítio, destinado a um cemitério, é imprescindível que o mesmo seja corretamente dimensionado e que se crie um programa racional de sepultamentos, tendo em vista proteger a área contra uma rápida saturação. E, para que os sepultamentos não constituam perigo para a saúde da população devem ser observadas as normas de higiene, quando existentes.

As substâncias cadavéricas, resultantes do processo de putrefação, conforme alguns estudos realizados, são portadoras de germes patogênicos e, quando transportadas por água de superfície, podem vir a se constituir em agentes de contaminação ambiental, poluindo rios, reservatórios e redes de distribuição de água. A escolha do solo é outro fator decisivo para a implantação de uma necrópole. Os cemitérios são, modernamente, considerados bens públicos de uso especial. Isso quer dizer que sua destinação é específica para fins de inumações de cadáveres humanos, além de estar sob a fiscalização do poder público, mesmo quando for de domínio privado. No que se refere aos problemas ambientais, na prática, há bastante polêmica sobre a instalação de necrópoles, principalmente quanto à proximidade de lençóis freáticos ou rios.

Segundo Castro (2008, p.252), as principais fontes poluidoras antrópicas em meios urbanos são as redes de esgoto e fossas sépticas, os aterros sanitários, atividades industriais, postos de armazenamento e distribuição de combustíveis e cemitérios, além de drenagens superficiais poluídas e deposição de resíduos sólidos não autorizados. Dentre estas, a poluição devido aos cemitérios ocorre de maneira mais assintomática para as percepções sensoriais da população, de forma 
silenciosa, porém contínua. Desde o início do século XXI os cemitérios foram apenas excepcionalmente incluídos nas listas de fontes tradicionais de contaminação ambiental, bem como têm sido raramente objetos de estudos geoambientais mais amplos e sistemáticos sobre as reais dimensões da contaminação do solo e água subterrânea causada pela decomposição de corpos humanos no meio geológico.

De acordo com Castro (2008, p.252) nos cemitérios, as fontes poluentes são pontuais, representadas por corpos dispostos separadamente em sepulturas. Estes produzem pequenas quantidades de necro-chorume, lentamente ao longo de 2,5 anos. A abertura e ocupação das covas seguem um cronograma específico, sendo as sepulturas preenchidas de maneira organizada em setores pré-determinados dentro da área de sepultamento do cemitério. Portanto, têm-se as áreas fonte da contaminação sendo deslocadas ao longo do tempo útil de uma necrópole. Neste sentido, um levantamento geofísico para a detecção das fontes poluentes deve considerar também o histórico de ocupação dos setores de sepultamento.

Segundo Martin (2008),

"o sepultamento de corpos em cemitérios horizontais, e a sua subseqüente
degradação podem, potencialmente, causar impactos negativos primários
das águas subterrâneas - aqüíferos e das águas superficiais e secundários,
poluição do solo, mediante a presença de substâncias residuárias como o
Arsênio e o Mercúrio utilizado no embalsamento. Formaldeídos na
preparação dos corpos e Chumbo, Ferro, Zinco e Cobre entre outros
utilizados em acessórios metálicos da urna de sepultamento. Desta
maneira, a implantação de cemitérios horizontais deve ser efetuada
mediante a realização de diferentes estudos ambientais cujo principal
objetivo está em investigar as potencialidades e problemas geotécnicos da
área destinada a tal implantação. Como também, evitar que a degradação
de corpos que tenham utilizado hormônios em tratamentos médicos e
principalmente o Líquido da Coaliquação contamine solo, água e também o
ar, afim de que, deste modo, evitem-se a proliferação de doenças de cunho
sanitário como a Dengue, por exemplo. Assim, o principal risco que pode
ser efetivamente associado à atividade dos cemitérios reside em possibilitar
a ocorrência ou disseminar doenças a partir de microrganismos, por contato
direto (risco maior para os funcionários) ou através das fontes de
abastecimento de água tanto para consumo humano quanto para outros
corpos d' água. "(MARTIN, 2008, p. 95)

De acordo com Barros (2008, p.1764), as partes metálicas dos caixões, como alças e adereços, são consideradas as principais fontes de contaminação dos solos de cemitério por metais pesados. Outras fontes de poluentes são os produtos usados no embalsamento de corpos, conservantes da madeira de caixões e líquidos humurosos liberados na decomposição. 
Segundo Barros (2008, p.1764), os caixões construídos de madeira não se apresentam como a principal fonte de contaminação do solo, a menos que conservantes da madeira fontes de metais pesados, principalmente $\mathrm{Cr}$, ou à base de organoclorados, como o pentaclorofenol, estejam presentes. Entretanto, madeiras não tratadas se decompõem rapidamente, permitindo uma rápida disseminação de líquidos humurosos. Caixões de metal, normalmente não utilizados em sepultamentos, podem causar contaminação do solo por $\mathrm{Fe}, \mathrm{Cu}, \mathrm{Pb}$ e $\mathrm{Zn}$ durante vários anos, especialmente em solos com baixo $\mathrm{pH}$. Contaminantes químicos, como As e $\mathrm{Hg}$, usados em práticas de embalsamento de corpos com formaldeído, podem ter sido responsáveis, no passado, pela contaminação do solo e da água em cemitérios. Atualmente, constituem-se em fontes de contaminantes químicos o verniz e conservantes da madeira e as partes metálicas dos caixões, como alças e adereços, que podem liberar $\mathrm{Pb}, \mathrm{Zn}, \mathrm{Cu}, \mathrm{Cr}$ e $\mathrm{Ni}$ e Fe.

Segundo Pacheco (1995, p.6) os cemitérios também podem provocar um impacto estético urbanístico. Este impacto é normalmente provocado pelos cemitérios tradicionais, cemitérios que estão no centro da cidade, em que os túmulos são a céu aberto, em áreas fragmentadas que impedem a infiltração de águas de chuvas. Por conseguinte, isto permite uma lavagem de túmulos em ruína e muitas vezes, estas águas são levadas para a área externa desses cemitérios. São cemitérios onde há uma carência de verde, de árvores, e o aspecto desses cemitérios é de um tom acinzentado, que nada contribuem para a estética da área urbana onde os mesmos se situam. Nestes cemitérios existem vasos com flores, sujeitos ao acúmulo de água, e esses vasos podem ser criadores do mosquito aedis egipcius, transmissor da dengue. Neste tipo de cemitério proliferam as baratas, o alimento preferido dos escorpiões, havendo a tendência do aparecimento destes, principalmente o escorpião thitius cerrulatus, de cor amarela, um dos mais venenosos do mundo. 


\section{MÉTODOS E TÉCNICAS DE PESQUISA}

A metodologia adotada foi a da pesquisa qualitativa, com um enfoque exploratório-descritivo, foi realizado um levantamento bibliográfico em artigos, livros e legislações acerca da atividade cemiterial no Brasil, além da realização de entrevista semi-estruturada junto a gestores de empresas que administram necrópoles, assim como visita a estes locais.

As entrevistas foram realizadas durante o mês de setembro, sendo contemplados os gestores que administram os cemitérios do Distrito Federal e o da maior cidade do Entorno do DF. Os gestores foram esclarecidos sobre o objetivo da pesquisa e colaboraram de forma muito contundente sobre o aspecto geral e específico da atividade cemiterial, de acordo com a experiência de cada profissional.

As pesquisas exploratórias, segundo Gil (1999, p. 43) visam proporcionar uma visão geral de um determinado fato, do tipo aproximativo. De acordo com Gil (1999, p. 46) um trabalho é de natureza exploratória quando envolver levantamento bibliográfico, entrevistas com pessoas que tiveram (ou tem) experiências práticas com o problema pesquisado e análise de exemplos que estimulem a compreensão. Possui ainda a finalidade básica de desenvolver, esclarecer e modificar conceitos e idéias para a formulação de abordagens posteriores. Dessa forma, este tipo de estudo visa proporcionar um maior conhecimento para o pesquisador acerca do assunto, a fim de que esse possa formular problemas mais precisos ou criar hipóteses que possam ser pesquisadas por estudos posteriores. De acordo com Godoy (1995, p. 62), a pesquisa qualitativa é essencialmente descritiva, esse tipo de estudo tem na palavra escrita sua melhor ferramenta, tanto para obtenção dos dados quanto para a divulgação dos resultados. Tem como objetivo compreender o fenômeno de forma ampla, onde o ambiente e as pessoas nele inseridas são observados como um todo, holísticamente.

As informações obtidas a partir do levantamento bibliográfico foram estudadas e interpretadas para permitir a formulação de avaliações qualitativas, conforme apresentados nos capítulos "Resultados e Discussão" e "Conclusões e Recomendações". 


\section{RESULTADOS E DISCUSSÃO}

A grande maioria dos cemitérios em operação no Brasil foi implantada antes da Resolução do Conselho Nacional do Meio Ambiente - CONAMA, № 335/2003, de 03 de abril de 2003, considerado o marco regulatório ambiental do setor. Provavelmente em razão da inexistência de instrumentos legais à época, não foram considerados em sua implantação estudos geológicos e hidrogeológicos, podendo estes empreendimentos tornar-se fonte de contaminação ambiental. São em sua esmagadora maioria cemitérios do tipo horizontais em que os corpos são sepultados em construções tumulares (jazigo, gaveta ou cripta) dotadas ou não de compartimentos para sepultamento, sendo que, muitas vezes, em contato direto com o solo. Sepultamentos deste tipo puderam ser verificados nas visitas a cemitérios do tipo horizontal do Distrito Federal e a um cemitério do Entorno do Distrito Federal, realizadas durante as entrevistas junto a gestores destes empreendimentos.

O cemitério do Entorno do Distrito Federal é um empreendimento particular com início de operação no ano de 1998, com uma média mensal de 30 sepultamentos, e os cemitérios do Distrito Federal, que de acordo com seu gestor tem uma média mensal de 900 sepultamentos, remontam o início de sua operação à década de 1960, quando da inauguração da Capital Federal, sendo públicos com contrato de concessão de gestão privada a partir de 2002. A Resolução CONAMA no $335 / 2003$ em seu artigos $1^{\circ}$ e $11^{\circ}$ requer que os cemitérios sejam submetidos ao processo de licenciamento ambiental e concede um prazo de 180 dias aos cemitérios existentes e licenciados a partir da publicação da resolução, para firmar termo de compromisso para adequação do empreendimento, prazo este dilatado por mais 2 anos pela Resolução CONAMA no 368/2006. Posteriormente, a Resolução CONAMA no 402/2008 delegou aos órgãos estaduais e municipais estabelecer até dezembro de 2010, critérios para adequação dos cemitérios existentes em 2003. Segundo seus gestores, o cemitério do Entorno possui Relatório de Impacto ao Meio Ambiente - RIMA e Estudo de Impacto Ambiental - EIA, sendo que os cemitérios do Distrito Federal possuem alvará de funcionamento.

Os empreendimentos tanto do Distrito Federal como do Entorno são fiscalizados, de acordo com seus gestores, pelo menos uma vez por ano, por órgãos ambientais como a Agência Reguladora de Águas e Saneamento do Distrito Federal 
- ADASA, Superintendência de Vigilância Sanitária e Ambiental do Estado de Goiás VISA, Agência Ambiental de Goiás - AAG, Secretaria de Vigilância Sanitária Municipal e Secretaria de Meio Ambiente Municipal. Além da Legislação Federal os cemitérios visitados seguem conforme o caso: Leis Municipais (163 de 20/03/1998, 277 de 14/06/2000, 293 de 16/10/2000, 401 de 23/12/2002 e 573 de 03/02/2005); Estadual (16140 de 02/10/2007) e Distrital (2424 de 13 de julho de 1999).

Para evitar a possibilidade de contaminação por necrochorume, a Resolução CONAMA no 335/2003 em seu artigo 5ํㅡㄴ, inciso I, prevê que a área de fundo das sepulturas deve manter uma distância mínima de um metro e meio do nível máximo do aqüífero freático, sendo que em todos os cemitérios visitados, de acordo com seus gestores, os níveis do lençol freático estão abaixo desse nível e as empresas utilizam do recurso de coleta trimestral de amostra de água, por intermédio de diversos poços de monitoramento, fato não previsto na Resolução CONAMA no 335/2003, para controle da qualidade da água e sua potabilidade, conforme as variáveis estipuladas na Portaria no 518/2004 do Ministério da Saúde, para apresentação as fiscalizações ambientais.

O cemitério localizado no Entorno do Distrito Federal conforme seu gestor é:

“... um cemitério horizontal estilo parque com a construção de jazigos
subterrâneos com gavetas em concreto armado, coberto por grama em sua
totalidade, apenas com uma placa de identificação do jazigo na superfície,
com economia de espaço, grama e jardins bens cuidados, cultivando uma
integração com a natureza e o ambiente, e preparados com um declive de
$5 \%$ na cobertura da grama, para drenagem de águas das chuvas. "

Quanto aos cemitérios do Distrito Federal foram de acordo com seu gestor:

"... concebidos para o estilo parque, os cemitérios do Distrito Federal, por motivos políticos, sociais e econômicos tiveram seu projeto arquitetônico alterado com a colocação de diversas anomalias nos jazigos, tais como vasos, bancos, correntes e outros adereços, fazendo com que o sistema parque mais se aproximasse de um cemitério convencional dificultando sua manutenção e tendo um forte impacto visual. A partir de $2002 \mathrm{com}$ a retomada o sistema parque foi implementada uma economia de espaço físico em relação ao que estava em utilização, na proporção de $7 \times 1$, além da amenização do visual e melhor drenagem das águas pluviais, com 0 plantio de grama e árvores complementando um ambiente menos agressivo." 
Ao adotarem o sistema parque com jazigos subterrâneos com gavetas em concreto armado, coberto por grama, os cemitérios evitam o contato com animais e insetos, tais como roedores e baratas, uma vez que o corpo fica totalmente enterrado e lacrado, minimizando o risco de gases nauseabundos, com a putrefação ocorrendo por calor. No Distrito Federal, a exceção ocorre nos sepultamentos do Serviço Social que são efetuados em jazigos escavados e nos quais os corpos nos caixões são sepultados diretamente na terra.

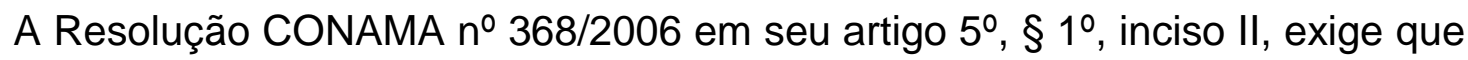
o perímetro e o interior do cemitério sejam providos de um sistema de drenagem destinado a captar, encaminhar e dispor de maneira segura o escoamento das águas pluviais, estando o cemitério do Entorno adaptado a resolução, enquanto os do Distrito Federal não em sua totalidade.

Apesar da Resolução CONAMA ํo $335 / 2003$ em seu artigo 8o não recomendar, isto é, ela não proíbe o emprego de plásticos, tintas, vernizes, metais pesados ou qualquer material nocivo ao meio ambiente nos sepultamentos, isto pode ocorrer, em um ponto em que os cemitérios não interferem, conforme relato dos gestores dos cemitérios:

"...acredito que o problema e possível causa de impacto ambiental está
muito mais localizado na preparação dos corpos antes da realização do
sepultamento, bem como do material utilizado na fabricação dos caixões e
demais adornos. O maior problema está na preparação dos corpos pelas
funerárias, em que pode existir a possibilidade de utilização indiscriminada
de produtos conservantes. "

No Distrito Federal o prazo para exumações é de 5 (cinco) anos, sendo que em outros locais é de 3 (três) anos. Os resíduos sólidos, não humanos, resultantes da exumação dos corpos deverão ter destinação ambiental e sanitária adequada, de acordo com o artigo 9o da Resolução CONAMA no 335/2003. No cemitério do Entorno de acordo com seu gestor:

\footnotetext{
" os resíduos são incinerados em forno crematório e são considerados lixo classe D (enquadrados como lixo Comum, não sendo considerados de Risco Biológico, Químico ou Radioativo) por terem passado por tratamento térmico, de acordo com a Resolução CONAMA no 316/2002 (que dispõe sobre procedimentos e critérios para o funcionamento de sistemas de tratamento térmico de resíduos), sendo coletados pelo governo municipal juntamente com o lixo classe D recolhido."
} 
No Distrito Federal em cumprimento ao mesmo artigo da Resolução CONAMA n 335/2003 os resíduos são recolhidos por empresa especializada que os transporta e incinera.

Tanto no cemitério do Entorno quanto nos do Distrito Federal segundo seus gestores :

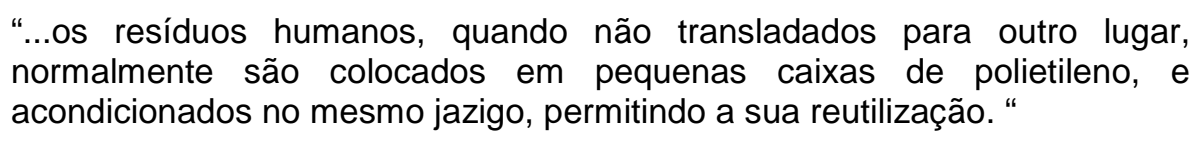
normalmente são colocados em pequenas caixas de polietileno, e acondicionados no mesmo jazigo, permitindo a sua reutilização. "

As empresas durante as atividades executadas nos cemitérios fornecem Equipamentos de Proteção Individual - EPIs, indicados para cada atividade, tais como luvas de procedimentos, máscaras, óculos, botas de borracha e roupas de proteção descartável, contando ainda o cemitério do Entorno com um Programa de Prevenção de Riscos Ambientais - PPRA, corroborando com Silva (2008) de que as atividades de sepultamento de cadáveres geram fontes poluidoras ao meio físico, sendo que assim devem ser consideradas como uma atividade - aspecto - impacto ambiental.

O cemitério do Entorno conta ainda com um crematório, regulado pela Resolução CONAMA no 316/2002, que atende a toda a região centro-oeste, inclusive ao Distrito Federal. No Distrito Federal de acordo com seu gestor, desde 2003 foi solicitada a liberação de um forno crematório para o Distrito Federal junto aos órgãos ambientais e o pedido ainda continua pendente. 


\section{CONCLUSÕES E RECOMENDAÇÕES}

Este trabalho de pesquisa reúne informações acerca da legislação existente para a implantação e manutenção da atividade cemiterial existente no Brasil, assim como a legislação ambiental, as possíveis formas de atendimento da população e seu impacto ambiental. Além disso, busca identificar a melhor alternativa para o meio ambiente e que, ao mesmo tempo, satisfaça as necessidades da população procurando esclarecer se as necrópoles constituem risco ambiental.

Desde o princípio da Humanidade, o ser Humano realiza a atividade de sepultamento de seus pares, sendo que com a influência do cristianismo o termo cemitério tomou o sentido de descanso após a morte. Ao longo da idade medieval a prática de enterrar em solo sagrado foi sendo ampliada e os solos destinados ao sepultamento de humanos passaram a se localizar próximos as igrejas, posteriormente, a partir da metade do século XVII estes locais passaram a ser localizados em áreas não próximas de igrejas.

Os cemitérios podem ser de dois tipos: o convencional, objeto de estudo deste trabalho, com sepulturas na posição horizontal e o vertical, que é um edifício, com vários níveis, pelos quais se distribuem os lóculos, cavidades onde são colocados os corpos.

O Brasil, segundo Andrade (2007, p. 45), em 1987, foi o primeiro país do mundo a ter normas de procedimentos ambientais voltadas para cemitérios, através da Companhia de Tecnologia de Saneamento Ambiental de São Paulo, por intermédio da edição da norma de procedimento interno CETESB L1040. Apesar desta iniciativa pioneira, somente em 2003, os cemitérios foram incluídos como empreendimentos licenciáveis no âmbito ambiental, através da Resolução do Conselho Nacional do Meio Ambiente - CONAMA, nํ335/2003, de 03 de abril de 2003, considerado o marco regulatório ambiental do setor.

A Resolução № 335/2003 dispõe acerca do licenciamento ambiental de cemitérios horizontais e verticais a serem implantados no Brasil, tendo sido delegado aos órgãos estaduais a obrigação de licenciar e fiscalizar a implantação de novos cemitérios. Aos cemitérios já existentes foi dado um prazo de dois anos após aquela data, para se adequarem as exigências junto aos órgãos ambientais competentes. Em 28 de março de 2006, foi promulgada a Resolução do Conselho 
Nacional do Maio Ambiente - CONAMA n 368, que altera alguns dispositivos nos artigos $3^{\circ}$ e $5^{\circ}$ da Resolução no 335 e concede um prazo de mais dois anos para os cemitérios se adequarem.

Posteriormente a Resolução CONAMA no 402/2008 delegou aos órgãos estaduais e municipais estabelecer, até dezembro de 2010, critérios para adequação dos cemitérios existentes em 2003. A esfera municipal é a responsável pela formulação de leis locais, e a determinação de normas é feita por órgãos ambientais da administração pública que compõem o Sistema Nacional do Meio Ambiente SISNAMA. As resoluções CONAMA funcionam como um instrumento de prevenção à poluição e de preservação dos recursos ambientais existentes.

Apesar das resoluções do Governo Federal, terem sido editadas a partir do ano de 2003, foi possível constatar que, apesar do tempo decorrido, os cemitérios públicos não se adequaram e preferem aguardar que a Resolução CONAMA no 402/2008 seja regulamentada pelos órgãos ambientais, numa ação muito mais reativa do que proativa na questão ambiental. Foi constatado também que a fiscalização dos órgãos ambientais e sanitários é muito mais atuante nos empreendimentos particulares que, por serem de instalação mais recente, estão em sua maioria adequados à legislação.

Apesar de não constar da legislação federal, um importante ponto de controle preventivo de eventual poluição do lençol freático foi encontrado nos cemitérios do Distrito Federal e Entorno, tanto no particular, quanto nos públicos, que é o monitoramento hidrogeológico da qualidade da água, por meio da coleta de amostra da água dos cemitérios por intermédio da perfuração de poços até o alcance do lençol freático. Estas amostras devem, para serem aprovadas, atender as condições de potabilidade conforme as variáveis estipuladas na Portaria no 518/2004 do Ministério da Saúde. Este item, em particular, deveria constar da legislação federal como específico relacionado a fiscalização obrigatória nos cemitérios.

Outro item da legislação federal que deveria ser revisto é o artigo 8o da Resolução CONAMA no 335/2003, que não recomenda, mas não proíbe, o emprego de plásticos, tintas, vernizes, metais pesados ou qualquer material nocivo ao meio ambiente nos sepultamentos. Este fato pode ser causador de impacto ambiental.

Para evitar a possibilidade de contaminação por necrochorume, foi possível concluir que deveria ser abolido o sepultamento diretamente no solo, utilizando-se a alternativa de sepultamentos em jazigos de concreto, que podem ser reutilizados 
após ter sido transcorrido o prazo de exumação, minimizando o risco de contaminação por necrochorume e proporcionando ganho de espaço físico. Este tipo de sepultamento no solo, que somente ocorre nas classes sociais menos favorecidas, deveria ser trocado para jazigos de concreto, o que causaria um impacto financeiro aos cofres públicos, e para que isso fosse possível em razão da pouca importância que os gestores públicos dão à atividade cemiterial pública, deveria ser implementado por meio de legislação especifica.

Outro importante item não encontrado na legislação federal, que pode constituir fonte de eventual impacto ambiental, é a inexistência de controle sobre a preparação dos corpos pelas funerárias e dos produtos conservantes utilizados, inclusive quanto a quantidade dos mesmos.

Durante a pesquisa, foi possível perceber que a população do Distrito Federal e do Entorno está plenamente atendida quanto as suas necessidades, porém, não observa em sua escolha o que seria a melhor alternativa para o meio ambiente.

De acordo com Silva (2000, p.178), a cremação é um processo alternativo a ser considerado seriamente no nosso contexto socioeconômico. É uma solução imediata, eficiente, higiênica, limpa, digna, rápida, econômica, moderna e sanitária. Possui um potencial resolutivo muito bom para alguns problemas ambientais que afligem um grande número de cidades brasileiras, em especial, a contaminação do solo e a poluição das águas subterrâneas. Como vantagem adicional, a cremação ainda é um processo de disposição dos corpos muito mais econômico do que o sepultamento tradicional. No entanto, por motivos principalmente culturais, a cremação de corpos ainda é muito pouco difundida no Brasil.

Outro método alternativo, não disponível no Brasil, considerado como o enterro menos agressivo ao meio ambiente, o método freeze-dry, por enquanto disponível desde 2005 apenas na Suécia, consiste em mergulhar o corpo em nitrogênio liquido. $O$ cadáver congelado é colocado para vibrar em uma esteira, sendo que bastam alguns minutos para que tudo se estilhasse e vire pó, posteriormente equipamentos filtram água e um ímã retira qualquer metal proveniente de próteses ou obturações. $O$ pó resultante $(20 \mathrm{~kg}$ a partir de um corpo de $80 \mathrm{~kg}$, por exemplo) é colocado em uma caixa de amido de batata ou milho e enterrado em um túmulo raso.

Por fim, vale dizer que, apesar de ser um empreendimento que mexe com os sentimentos e com a memória das pessoas, os cemitérios precisam que sua 
implantação e operação sejam processadas com técnicas adequadas de proteção e de preservação do meio ambiente. É de suma importância licenciar, monitorar, fiscalizar e acompanhar este tipo de empreendimento, com vistas a preservar o meio ambiente. Considerando a importância do tema ambiental e com base na pesquisa realizada, sugiro que os gestores de cemitérios implantem um programa de Educação Ambiental visando a conscientização de visitantes, funcionários e da própria comunidade do entorno dos cemitérios, para alavancar a percepção da necessidade de conservação do meio ambiente.

Por meio deste trabalho, apesar da escassez de material específico sobre o tema, pude constatar que os cemitérios que estão adequados as resoluções CONAMA, tem menor possibilidade de apresentar risco ambiental do que aqueles que ainda não o fizeram ou não tem condições de fazê-lo. Apesar disso, com um gerenciamento adequado, este risco pode ser considerado controlável se considerado o poder de contaminação de outras atividades.

Este trabalho, além de me possibilitar atingir os objetivos propostos e responder ao questionamento inicial, me proporcionou a oportunidade de conhecer uma atividade que gera certa discriminação. Além disso pude por meio do levantamento e crítica da legislação, constatar que a legislação federal que trata de cemitérios precisa ser aprimorada. Desta forma, espero ter contribuído para a reflexão de um tema tão importante como os monumentos à memória daqueles que morreram e os impactos destes ao ambiente. 


\section{REFERÊNCIAS}

ANDRADE, Flavio F.A., A Ameaça dos Mortos, Editora e Gráfica Maxprint, Jundiaí, SP, 2007.

BARROS, Yara Jurema, Teores de Metais Pesados e Caracterização Mineralógica de Solos do Cemitério Municipal de Santa Cândida, Curitiba (PR), Revista Brasileira de Ciências do Solo, Vol. 32, № 4, Viçosa, Jul./Ago.2008

BRASIL. Conselho Nacional do Meio Ambiente. Resolução no 316, de 29 de outubro de 2002. Dispõe sobre procedimentos e critérios para o funcionamento de sistemas de tratamento térmico de resíduos. Disponível em: $<$ http://www.mma.gov.br/port/conama/res/res02/res31602.html >, acesso em 03 de maio de 2010.

BRASIL. Conselho Nacional do Meio Ambiente. Resolução no 335, de 03 de abril de 2003. Dispõe sobre o licenciamento ambiental de cemitérios. 2003. Disponível em: < http://www.areaseg.com/conama/2003/335-2003.pdf>, acesso em 03 de maio de 2010.

BRASIL. Conselho Nacional do Meio Ambiente. Resolução ํo 368, de 28 de março de 2006. Altera dispositivos da Resolução no 335, de 3 de abril de 2003, que dispõe sobre o licenciamento ambiental de cemitérios. 2006. Disponível em:< http://www.comitepcj.sp.gov.br/download/Res-CONAMA-368-06.pdf >. Acesso em: 03 de maio de 2010.

BRASIL. Conselho Nacional do Meio Ambiente. Resolução no 402, de 17 de novembro de 2008. Altera dispositivos da Resolução oㅜ 335, de 3 de abril de 2003, que dispõe sobre o licenciamento ambiental de cemitérios. 2006. Disponível em:< http://www.mp.sp.gov.br/portal/page/portal/cao urbanismo e meio ambiente/destaq ues/ResCONAMA\%20402-2008.pdf>. Acesso em: 03 de maio de 2010. 
BRASIL. Ministério da Saúde. Portaria n 518, de 28 de março de 2006. Estabelece os procedimentos e responsabilidades relativos ao controle e vigilância da qualidade da água e outras providências. Disponível em: < http://portal.saude.gov.br/portal/arquivos/pdf/portaria 518 2004.pdf>. Acesso em: 18 de setembro de 2010 .

CASTRO, David Lopes, Caracterização Geofísica e Hidrogeológica do Cemitério Bom Jardim, Fortaleza - CE, Revista Brasileira de Geofísica, Vol. 26, № 3, São Paulo, Jul./Set. 2008

CETESB - Companhia de Tecnologia de Saneamento Ambiental. Manual de gerenciamento de áreas contaminadas, CETESB, São Paulo, Outubro/2001, Disponível em: http://www.cetesb.sp.gov.br/solo/areas contaminadas/manual.asp, Acesso em: 05 de maio de 2010.

GIL, Antônio Carlos, Métodos e técnicas de pesquisa social, Editora Atlas, São Paulo, 1999.

GODOY, Arilda Schmidt, Introdução à pesquisa qualitativa e suas possibilidades. Revista de Administração de Empresas. São Paulo: v.35, n.2, p. 57-63, março/abril 1995.

LINK, Volker Reinhold, Impactos Ambientais e Sociais do Uso e Ocupação do Solo, Revista DAE/Sabesp, no 139, dezembro de 1984, requisitada em 04 de maio de 2010 junto à biblioteca on-line da Sabesp em< http://www.revistadae.com.br>

MACHADO, Silvestre Sales, Analise Ambiental dos Cemitérios: Um Desafio Atual para a Administração Publica, Revista de Ciências Humanas, Vol. 6, no 1, p. 127144, Jan./Jun.2006

MARTIM, Aline G. Aspectos do Meio Físico a serem observados para Implantação de Cemitérios Horizontais, Revista Agroambiente On-line, Vol. 2, № 1, 2008, disponível: http://www.ufrr.br/revista/index.php/agroambiente/article/viewArticle/168, acesso em 26/08/2010. 
PACHECO, Alberto Pacheco, Cemitérios e Meio Ambiente, Revista Tecnologias do Ambiente, Lisboa, Ano 7, no 33, 2000.

PACHECO, Alberto Pacheco, Cemitério e o Impacto nas Águas Subterrâneas, Palestra realizada no Primeiro Seminário Nacional de Cemitério e Meio Ambiente, São Paulo, Junho de 1995

SILVA, Leziro Marques, Cremação - Método Alternativo para a Disposição de Cadáveres, Centro de Pesquisa da Universidade São Judas Tadeu, Revista Integração, Ano VI, № 22, São Paulo, Agosto/2000

SILVA, Robson Willians Costa, Cemitérios como Áreas Potencialmente Contaminadas, Revista Brasileira de Ciências Ambientais, Abril/2008.

SILVA, Robson Willians Costa, Cemitérios Fontes Potenciais de Contaminação, Revista Ciência Hoje, Volume 44, № 263, setembro/2009

SILVA, Robson Willians da Costa, Emprego do Método da Eletrorresistividade no Estudo da Contaminação Subterrânea do Cemitério Municipal de Vila Rezende, Piracicaba - SP, Revista Brasileira de Geofísica, Vol. 27, № 3, São Paulo, Jul./Set. 2009 


\section{APÊNDICES}

\section{Apêndice A - Questionário aplicado na pesquisa}

1. A organização conhece as resoluções CONAMA no. 335/2003 (cemitérios), 368/2006(cemitérios) e 316/2002 (crematórios) e possui Licença Ambiental concedida naqueles termos?

Objetivo da pergunta - Verificar se a empresa possui licença ambiental concedida com base nessas resoluções do CONAMA, que contêm obrigações e proibições relacionadas com as questões ambientais.

2 - Sabe-se a que profundidade se encontra o lençol freático nos cemitérios administrados pela organização? Há monitoramento da qualidade da água?

Objetivo da pergunta - Verificar se o lençol freático está a mais de $1,5 \mathrm{~m}$ de profundidade, conforme recomenda a resolução CONAMA 335/2003.

3 - Os cemitérios possuem sistema de drenagem de águas das chuvas?

Objetivo da pergunta - Verificar se atende à resolução CONAMA 335/2003.

4 - A empresa tem conhecimento de que cemitérios podem produzir contaminantes de largo expectro nas suas proximidades e dos riscos ambientais decorrentes? Utiliza algum método para impedir ou reduzir essa contaminação?

Objetivo da pergunta - Verificar se as águas coletadas nas proximidades revelaram presença de índices elevados de coliformes fecais, estreptococos fecais, bactérias diversas, Salmonella, elevados teores de nitratos e metais como alumínio, cromo, cádmio, manganês, bário e chumbo.

5 - Quais são os cuidados ambientais tomados pela empresa quanto ao sepultamento?

Objetivo da pergunta - Levantar os cuidados ambientais adotados pela empresa e depois comparar com o referencial existente. 
6 - Como são tratados os resíduos produzidos nos cemitérios, e após quanto tempo? Objetivo da pergunta - Verificar 0 tratamento e tempo médio de decomposição/eliminação dos resíduos e comparar com o referencial existente.

7 - Como são tratados os resíduos produzidos nos fornos crematórios?

Objetivo da pergunta - Verificar o tratamento dos resíduos e comparar com o referencial existente.

8 - Quais são os resultados esperados pela empresa em relação à redução do impacto ambiental com os cuidados já tomados?

Objetivo da pergunta - Verificar se a empresa vem adotando medidas e está monitorando o impacto ambiental resultante de suas atividades.

9 - Que tipo de problema ou fatores dificulta a realização de ações ambientalmente corretas no desempenho das atividades da empresa?

Objetivo da Pergunta - Levantar os problemas que a empresa tem para adotar políticas ambientais adequadas.

10 - A organização conhece a certificação ISO 14.001 e a série de normas associadas a ela?

Objetivo da pergunta - Avaliar se a empresa conhece a certificação e se tem interesse em obtê-la.

11 - A empresa costuma receber fiscalizações ambientais? Quais? Recebe com freqüência?

Objetivo da pergunta - Verificar quais órgãos são os responsáveis pela aplicação da legislação ambiental e em que freqüência ocorre.

12 - A empresa possui um sistema de gestão ambiental, ou utiliza ferramentas ou instrumentos para auxiliar na gestão ambiental?

Objetivo da pergunta - Verificar se a organização possui um SGA. 
13 - Qual a diferença em utilização do espaço físico utilizado pelo método adotado pela empresa na construção dos jazigos e o método anteriormente utilizado pelo poder público?

Objetivo da pergunta - Verificar se apenas com a mudança de método houve um melhor aproveitamento do espaço físico, com menor impacto ao meio ambiente.

14 - Qual a melhoria ambiental trazida pelo modelo tipo parque?

Objetivo da pergunta - Verificar em termo de visual, produção de lixo, proliferação de insetos.

15 - Qual o tempo necessário para a decomposição e exumação, com reaproveitamento do espaço pela própria família?

Objetivo da pergunta - Verificar qual o tempo médio em que o meio ambiente tem risco de contaminação e se há reaproveitamento, otimização do espaço físico.

16 - Qual o destino das exumações?

Objetivo da pergunta - Verificar o tratamento e tempo médio de decomposição/eliminação dos resíduos e comparar com o referencial existente.

17 - Qual o destino dos resíduos das exumações e cremações, como caixões e outros?

Objetivo da pergunta - Verificar a condução dada aos resíduos e comparar com o referencial existente.

18 - O crematório possui algum tipo de filtro antipoluente?

Objetivo da pergunta - Verificar se há obrigação legal ou atitude preventiva.

19 - Quantas pessoas são cremadas e sepultadas mensalmente?

Objetivo da pergunta - Quantificar o número.

20 - Qual a legislação estadual vigente em relação ao cemitério e crematório?

Objetivo da pergunta - Verificar as leis estaduais vigentes. 
21 - Existe algum cuidado quando ocorre o sepultamento de alguém cuja causa mortis seja uma doença infecciosa?

Objetivo da pergunta - Verificar o processo e confrontar com o referencial existente. 